\title{
Abstract
}

\section{Will Expanding Health Care Coverage for People with Disabilities Increase their Employment and Earnings? Evidence from an Analysis of the SSI Work Incentive Program}

\author{
David C Stapleton and Adam Tucker
}

Reports findings from study that examines the effect that increases in the income threshold under the Supplemental Security Income (SSI) work incentive program have on the employment, earnings, and program participation patterns of SSI recipients. Under Section 1619 of the Social Security Act, SSI recipients may maintain Medicaid eligibility, even if their income is above the level that makes them ineligible for SSI payments. If earnings increase beyond the threshold, however, the person loses their SSI and Medicaid eligibility. Findings indicate that many SSI recipients restrain their earnings to stay below the threshold, supporting the hypothesis that lack of access to health insurance is an important work disincentive for people with disabilities.

Published in: In D. Salkever \& A. Sorkin (Eds.), Research in Human Capital and Development, 13, pp. 133-180, Stamford, CT: JAI Press. For full text see publisher's website:

http://www.elsevier.com/wps/find/bookdescription.cws_home/620752/descri ption\#description 